\title{
Fish Pond Effluent Effect on Physicochemical Properties of Soils in Southern Guinea Savanna, Nigeria
}

\author{
John Jiya Musa1*, Pius Olusegun Olufemi Dada², Johnson Kayode Adewumi², \\ Otuaro Ebierni Akpoebidimiyen ${ }^{3}$, Elijah Tsado Musa4, Martins Yusuf Otache ${ }^{1}$, Seun Yusuf ${ }^{1}$ \\ ${ }^{1}$ Department of Agricultural and Bioresources Engineering, Federal University of Technology, Minna, Nigeria \\ ${ }^{2}$ Department of Agricultural and Bioresources Engineering, Federal University of Agriculture, Abeokuta, Nigeria \\ ${ }^{3}$ Central Research Laboratory, University of Ilorin, Ilorin, Nigeria \\ ${ }^{4}$ Department of Civil Engineering, Delta State University, Oleh Campus, Nigeria \\ Email: *johnmusa@futminna.edu.ng
}

How to cite this paper: Musa, J.J., Dada, P.O.O., Adewumi, J.K., Akpoebidimiyen, O.E., Musa, E.T., Otache, M.Y. and Yusuf, S. (2020) Fish Pond Effluent Effect on Physicochemical Properties of Soils in Southern Guinea Savanna, Nigeria. Open Access Library Journal, 7: e5990.

https://doi.org/10.4236/oalib.1105990

Received: December 10, 2019

Accepted: January 13, 2020

Published: January 16, 2020

Copyright $\odot 2020$ by author(s) and Open Access Library Inc.

This work is licensed under the Creative Commons Attribution International License (CC BY 4.0).

http://creativecommons.org/licenses/by/4.0/

\begin{abstract}
This work studied the effect of fish pond wastewater, proximate and mineral analyses of the fish feeds from commercial fish ponds on receiving soils in the southern Guinea Savanna ecological zone of Minna, Nigeria. The study conducted during the dry seasons of the years 2015 and 2016 between January and May. Four sets of soil samples were collected at varying distances from the various fish ponds and analysed for physicochemical properties, Particle size analysis and Exchangeable Acidity. Similarly, two different sets of water samples were collected each from various farms studied and analysed for physicochemical properties such as $\mathrm{pH}, \mathrm{E}_{\mathrm{c}}$ (Electrical conductivity), TDS (Total dissolved solids), Alkalinity, Total Hardness, Turbidity, Temperature, DO (Dissolved Oxygen), BOD (Biological oxygen demand), Calcium, Magnesium, Sodium and Potassium. Average results obtained for the two dry seasons for the soil samples around the fish farms showed that: $\mathrm{pH} 6.33$ - 7.24, Organic Carbon $2.03-6.00 \mathrm{~g} / \mathrm{kg}$, Available Phosphorus $7-10 \mathrm{mg} / \mathrm{kg}$, Total Nitrogen 0.95 - $2.10 \mathrm{~g} / \mathrm{kg}$, Exchangeable Bases and Exchangeable Acidity $0.02-0.06 \mathrm{Cmol} / \mathrm{kg}$ were within the permissible limits of FAO and WHO. The various parameters were within the permissible limits for fish production. The fish wastewater had Electrical Conductivity $118-230 \mu \mathrm{S} / \mathrm{cm}, \mathrm{pH} 6.79-7.10$, and Biological Oxygen Demand $3.0-6.0 \mathrm{mg} / \mathrm{L}$. In conclusion, the wastewater from fish farms is good sources of fertiliser to the surrounding farmlands.
\end{abstract}

\section{Subject Areas}

Marine Biology, Microbiology 


\section{Keywords}

Farm, Feed, Water, Waste, Soil

\section{Introduction}

With the drive of the Nigerian government towards revamping agricultural activities in the country, there is the need to reconsider the various inputs which are currently in use by the local farmers. Water as a resource is gradually becoming increasingly scarce, and there is a need to sustain it globally and locally [1]. The increasing need for water in most parts of the world especially the arid and semiarid regions has resulted in the emergence of wastewater for agriculture [2]. Today, wastewater has become a matter of grave concern, as it is an essential component of our environment which is mostly used to irrigate farmland, reduce soil salinity and increase the soil moisture content [3]. In our immediate environment today, a large amount of water is being used for various industrial purposes, and upon the full utilisation of the water, it is discharged directly to surrounding soil or surface water and thereby contaminating both the soil and groundwater [4].

Most industries have continuously deposited much wastewater into the surrounding containing a high level of heavy metals, nutrients and hazardous substances into agricultural land [5]. However, most wastewater usually has high nutritive content that might improve plant growth and productivity [6]. Soil irrigated with wastewater had been shown to contain $4.1 \%$ of organic particles by weight, but these particles contain up to $47.8 \%$ of the total soil carbon and $41.7 \%$ of nitrogen, and thereby represent necessary storage of both energy and nutrient for microorganisms [7]. Wastewater has been described as both "a resource and a problem" as such; the challenges are maximising the resource potential and minimising the problems associated with it [8].

Effluent released into the environment with an enhanced concentration of nutrient, sediment and toxic substances, may have serious undesirable effects on the quality of the receiving water body and soil when discharged without proper treatments [9]. This effluent can alter the properties of the receiving water body and soil [10] [11]. The first effect of liquid waste is to degrade the physical and chemical quality of both water and soil [12]. They further stated that an increase in population growth, rapid industrialisation and urbanisation around the world had created severe problems of soil and water pollution.

Local and sustainable farmers generally believe that wastewater from whichever source improves soil fertility which leads to high yield of farm produce. The impact of wastewater on agricultural soil is mainly due to the presence of high nutrient contents of Nitrogen and Phosphorus, high total dissolved solids and other constituents such as heavy metals [2]. Wastewaters also tend to contain salts that may accumulate in the root zone of crops which is believed to be 
harmful to crops grown in such fields [13] [14].

Wastewater from fish ponds is sometimes used as a potential irrigation source for raising vegetables around the sites which are directly or indirectly consumed by human beings [15]. Soil contamination by liquid farm wastes and industrial effluents has adverse effects on soil health and crop productivity [16]. Many untreated and contaminated liquid farm waste may have a high concentration of various heavy metals such cadmium $(\mathrm{Cd})$, nickel $(\mathrm{Ni})$, lead $(\mathrm{Pb})$ and chromium (Cr) [17].

This study aims to determine the effects of fish pond wastewater on the physical and chemical properties of some selected soils in Minna, Southern Guinea Savanna Ecological Zone of Nigeria and to investigate the relationship between the feeds, wastewater and the soil in the study area.

\section{Material and Method}

\subsection{Site Description}

Minna is located between latitude $9^{\circ} 34^{\prime}-9^{\circ} 37^{\prime} \mathrm{N}$ and longitude $6^{\circ} 36^{\prime}-6^{\circ} 39^{\prime} \mathrm{E}$, with an annual rainfall of $578 \mathrm{~mm}$ and a mean temperature of $34^{\circ} \mathrm{C}$ [18]. They also stated that Minna has a subtropical climate and its pattern of rainfall is characterised by a long term mean annual rainfall which starts from May to October with an average relative humidity of $48.9 \%$ and average monthly relative humidity ranges from $21 \%$ in February to $73 \%$ in August. Minna also has a distinct dry season that may occur from November to March. This is typical of states located within the southern Guinea Savanna ecological zone of Nigeria. Figure 1 is a map of Niger State show all the location of Minna; it's capital on the eastern part of the state and locations of the sample sites.

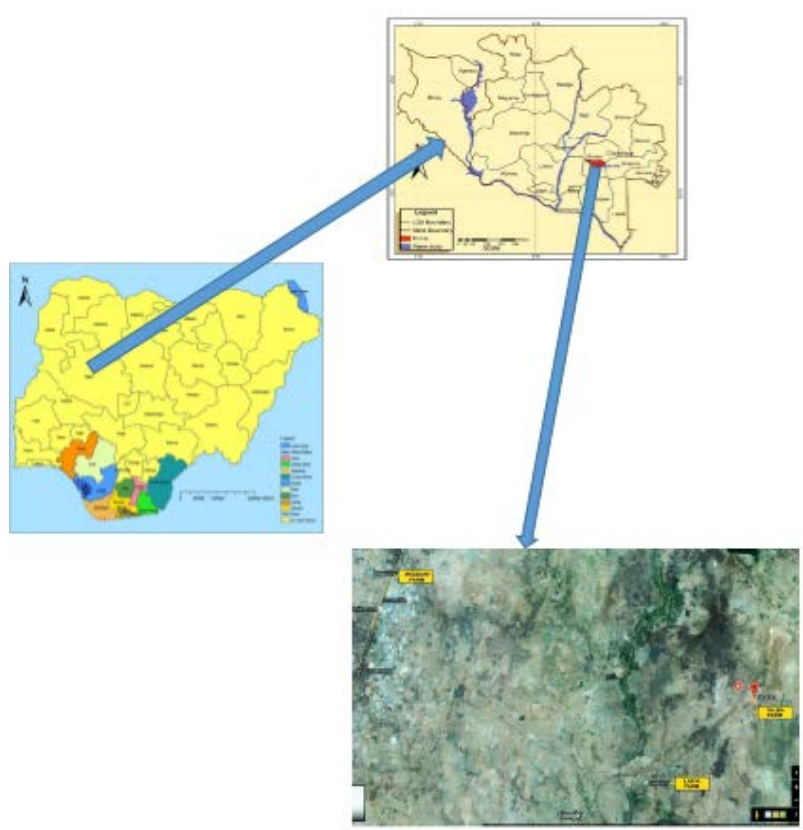

Figure 1. Google map of study area extracted from the map of Niger State. 


\subsection{Experimental Procedures}

The study was conducted during the dry seasons of the years 2015 and 2016 between January and May. During that period, four sets of soil samples were collected at varying distances from the various fish ponds and analysed for physicochemical properties, Particle size analysis and Exchangeable Acidity. Similarly, two different sets of water samples were collected each from various farms studied and analysed the physicochemical properties. Table 1 below indicates the coordinates of the various farms visited which were obtained using a Global positioning system (GPS) of Garmin Channel 72 model.

\subsection{Sample Collection}

During the period of study, water samples collected in sterilised clean plastic bottles; soil samples were collected in transparent polythene bags while the fish feeds collected in clean polythene bags. Using standard procedures as identified by several researchers [19] [20] [21] [22]. The collected water samples analysed for the following parameters $\mathrm{pH}, \mathrm{E}_{\mathrm{c}}$ (Electrical conductivity), TDS (Total dissolved solids), Alkalinity, Total Hardness, Turbidity, Temperature, DO (Dissolved Oxygen), BOD (Biological oxygen demand), Calcium, Magnesium, Sodium and Potassium. Collected soil samples were analysed for $\mathrm{pH}$, Particle size, Organic Carbon, Available Phosphorus, Total Nitrogen, Exchangeable Bases $\left(\mathrm{Na}^{+}, \mathrm{K}^{+}, \mathrm{Mg}^{2+}\right.$ and $\left.\mathrm{Ca}^{2+}\right)$ and Exchangeable Acid. Collected fish feeds were analysed for Nitrogen, Phosphorus, Potassium, Moisture content, crude fibre, Crude lipid, ash content and crude protein. The method employed for the analysis of the samples was following the works of Ayuba and Iorkohol [23]. The soil samples were air dried at room temperature for 48 hours before the analyses were conducted. The standard procedures identified by Nauman \& Khelid, Amin and Ojobor \& Tobih [19] [24] [25] were used to identify the soil pH, particle size distribution, exchangeable bases, exchangeable acidity, total Nitrogen, available phosphorus and organic carbon.

\subsection{Statistical Analysis}

Corrolation analysis was carried out for all the information collected during the course of the study using SPSS 17. The Pearson's correlation analysis was done to determine the degree of relationship between the wastewater, soils and the fish feed samples.

\section{Results and Discussion}

The results for the wastewater samples from the various fish farm settlements, samples of the various sources of water used on the various fish farms and soil samples analysed are presented in Table 2 while the analysis for the soil samples are presented in Table 3. The proximate and mineral analysis of the fish feed samples are presented in Table 4 and Table 5 respectively, while Table 6 is the Correlation coefficients ( $\mathrm{r}$ ) between N, P and K for the study area. 
Table 1. Location of the various farms considered for the study.

\begin{tabular}{ccccccc}
\hline S/N & Farm Name & $\begin{array}{c}\text { No. of } \\
\text { ponds } \\
\text { studied }\end{array}$ & $\begin{array}{c}\text { Distances } \\
\text { between } \\
\text { ponds }(\mathrm{m})\end{array}$ & $\begin{array}{c}\text { Distances between } \\
\text { points of sample } \\
\text { collection }(\mathrm{m})\end{array}$ & Longitude & Latitude \\
\hline 1 & Talba Farm & 8 & 7 & 10 & $6^{\circ} 52^{\prime} 09^{\prime \prime} \mathrm{E}$ & $9^{\circ} 53^{\prime} 29^{\prime \prime} \mathrm{N}$ \\
2 & Messohi Farm & 8 & 7 & 10 & $6^{\circ} 47^{\prime} 65^{\prime \prime} \mathrm{E}$ & $9^{\circ} 54^{\prime} 28^{\prime \prime} \mathrm{N}$ \\
3 & LapiaGwari farm & 35 & 8 & 10 & $6^{\circ} 50^{\prime} 44^{\prime \prime} \mathrm{E}$ & $9^{\circ} 52^{\prime} 68^{\prime \prime} \mathrm{N}$ \\
\hline
\end{tabular}

Table 2. Results for the analysis of the waste and source water samples.

\begin{tabular}{cccccccccccc}
\hline$S / N$ & Parameter & $A$ & $B$ & $C$ & $D$ & $E$ & $B S W 1$ & $R S W 2$ & $B S W 3$ & WHO & FWS \\
\hline 1 & $\mathrm{E}_{\mathrm{c}}(\mu \mathrm{S} / \mathrm{cm})$ & 133 & 121 & 140 & 137 & 142 & 205 & 118 & 230 & NS & $100-1000$ \\
2 & $\mathrm{pH}$ & 6.81 & 6.85 & 6.8 & 6.79 & 6.87 & 7.1 & 6.95 & 7.07 & $6.5-8.5$ & $6.5-9.5$ \\
3 & $\mathrm{DO}(\mathrm{mg} / \mathrm{L})$ & 6 & 7 & 6.2 & 5.8 & 6 & 4 & 8 & 5 & $6.5-8.5$ & $<5$ \\
4 & BOD $(\mathrm{mg} / \mathrm{L})$ & 5 & 4.5 & 4.3 & 4 & 6 & 3 & 4.7 & 3.7 & 6 & $6-\mathrm{Mar}$ \\
5 & TH CaCO $(\mathrm{mg} / \mathrm{L})$ & 295 & 270 & 255 & 280 & 322 & 330 & 400 & 110 & 600 & $50-150$ \\
6 & Alkalinity $(\mathrm{mg} / \mathrm{L})$ & 132 & 116 & 125 & 128 & 140 & 148 & 190 & 80 & 600 & $50-150$ \\
7 & Temp. $\left({ }^{\circ} \mathrm{C}\right)$ & 27 & 29 & 28 & 28 & 28 & 27.5 & 29 & 26.9 & Ambient & $25-30$ \\
8 & TDS $(\mathrm{mg} / \mathrm{L})$ & 330 & 500 & 458 & 552 & 407 & 118 & 829 & 120 & 500 & - \\
9 & Turbidity (NTU) & 130 & 270 & 300 & 286 & 159 & 10 & 620 & 5 & 10 & - \\
10 & Calcium (mg/L) & 24.2 & 19.34 & 20.41 & 20.5 & 23.64 & 32.3 & 31.03 & 26.26 & 200 & $25-100$ \\
11 & Sodium (mg/L) & 127 & 166 & 158 & 160 & 132 & 3 & 8.8 & 3.2 & 200 & - \\
12 & Potassium (mg/L) & 61.73 & 82.34 & 79.57 & 80.21 & 63.1 & 6.4 & 3.3 & 6.6 & 100 & - \\
13 & Magnesium (mg/L) & 20.61 & 25.4 & 38.23 & 29.92 & 30.5 & 28.19 & 30.23 & 20.52 & 200 & $25-100$ \\
14 & Phosphate (mg/L) & 0.51 & 1.02 & 0.84 & 1.3 & 0.71 & 0.32 & 0.65 & 0.11 & - & $0.03-2.0$ \\
15 & Nitrate (mg/L) & 2.53 & 3.1 & 3.21 & 3.45 & 2.82 & 4.02 & 6.05 & 4.13 & 50 & $0.1-4.0$ \\
\hline
\end{tabular}

NS $=$ Not Stated, E.C $=$ Electrical conductivity, Temp. $=$ Temperature DO $=$ Dissolved Oxygen, $\mathrm{TH}=$ Total Hardness, TDS $=$ Total Dissolved Solids, $\mathrm{BOD}=$ Biological Oxygen Demand, A = Fish wastewater from pond 1, B = Fish wastewater from pond 2, C = Fish wastewater from pond 3, D = Fish wastewater from pond 4, E = Fish wastewater from pond 5. BSW1 = Borehole source water for pond 1, RSW2 = River source water for pond 2, $3 \& 4$ and BSW3 = Borehole source water for pond 5. WHO = World Health Organization (2009), FWS = Fish Water Standards (Ehigbonare and Ogunrinde, 2010).

Table 3. Analysis results for the soil samples from the ponds studied.

\begin{tabular}{|c|c|c|c|c|c|c|c|c|c|c|c|c|c|c|}
\hline \multirow[t]{2}{*}{ Pond } & \multirow[t]{2}{*}{$S / N$} & \multicolumn{2}{|c|}{$p H$} & \multirow[t]{2}{*}{$O / C(g / k g)$} & \multirow[t]{2}{*}{$A P(m g / k g)$} & \multirow[t]{2}{*}{$T N(g / k g)$} & \multicolumn{4}{|c|}{ Cations ( $\mathrm{mg} / \mathrm{kg}$ ) } & \multicolumn{3}{|c|}{ Particle Size (\%) } & \multirow{2}{*}{$\begin{array}{l}\text { Exchangeable } \\
\text { Acid (Cmoll kg) }\end{array}$} \\
\hline & & $H 20$ & $\mathrm{CaCl}$ & & & & $\mathrm{Na}$ & $K$ & $M g$ & $\mathrm{Ca}$ & Sand & Silt & Clay & \\
\hline \multirow{4}{*}{1} & 1 & 6.52 & 5.44 & 6.00 & 10 & 2.10 & 1.70 & 2.30 & 18.50 & 41.20 & 75 & 8 & 17 & 0.06 \\
\hline & 2 & 6.54 & 5.61 & 5.62 & 10 & 1.58 & 1.60 & 1.80 & 14.00 & 35.30 & 72 & 9 & 19 & 0.03 \\
\hline & 3 & 6.60 & 5.65 & 4.80 & 9 & 1.43 & 1.50 & 1.60 & 13.40 & 24.40 & 76 & 8 & 16 & 0.04 \\
\hline & Ct. & 6.94 & 5.92 & 3.60 & 10 & 1.11 & 1.30 & 1.00 & 9.30 & 8.90 & 80 & 7 & 13 & 0.04 \\
\hline \multirow{4}{*}{2} & 1 & 6.48 & 5.35 & 4.33 & 10 & 1.58 & 2.00 & 2.50 & 16.60 & 41.00 & 78 & 7 & 15 & 0.06 \\
\hline & 2 & 6.57 & 5.43 & 3.58 & 8 & 1.30 & 1.60 & 2.20 & 13.00 & 29.80 & 80 & 8 & 12 & 0.05 \\
\hline & 3 & 6.63 & 5.52 & 3.20 & 10 & 1.26 & 1.60 & 1.90 & 10.40 & 26.30 & 82 & 8 & 10 & 0.05 \\
\hline & Ct. & 7.03 & 5.90 & 2.03 & 7 & 0.95 & 1.70 & 1.20 & 6.00 & 19.70 & 83 & 7 & 10 & 0.04 \\
\hline
\end{tabular}




\section{Continued}

\begin{tabular}{|c|c|c|c|c|c|c|c|c|c|c|c|c|c|c|}
\hline \multirow{4}{*}{3} & 1 & 6.40 & 5.34 & 4.32 & 9 & 1.43 & 1.80 & 1.90 & 17.00 & 39.70 & 73 & 9 & 18 & 0.06 \\
\hline & 2 & 6.62 & 5.56 & 3.59 & 10 & 1.32 & 1.90 & 1.90 & 15.00 & 28.80 & 76 & 8 & 16 & 0.05 \\
\hline & 3 & 6.80 & 5.72 & 3.27 & 10 & 1.29 & 1.80 & 1.60 & 12.80 & 25.60 & 80 & 6 & 14 & 0.06 \\
\hline & Ct. & 7.14 & 5.87 & 2.54 & 8 & 1.02 & 1.80 & 1.00 & 9.40 & 18.50 & 83 & 7 & 10 & 0.03 \\
\hline \multirow{4}{*}{4} & 1 & 6.70 & 5.52 & 3.89 & 10 & 1.40 & 1.70 & 2.10 & 17.90 & 37.90 & 78 & 8 & 14 & 0.05 \\
\hline & 2 & 6.42 & 5.40 & 3.55 & 9 & 1.35 & 1.60 & 1.60 & 15.20 & 28.30 & 80 & 8 & 12 & 0.05 \\
\hline & 3 & 6.20 & 5.24 & 3.38 & 9 & 1.33 & 1.50 & 1.50 & 13.00 & 26.40 & 82 & 7 & 11 & 0.03 \\
\hline & Ct. & 6.86 & 5.63 & 3.00 & 7 & 0.99 & 1.60 & 0.90 & 10.40 & 19.50 & 83 & 6 & 11 & 0.02 \\
\hline \multirow{4}{*}{5} & 1 & 6.82 & 5.52 & 4.10 & 8 & 1.53 & 3.20 & 4.50 & 18.00 & 40.00 & 78 & 8 & 14 & 0.05 \\
\hline & 2 & 6.33 & 5.60 & 3.98 & 8 & 1.48 & 2.60 & 3.00 & 15.20 & 34.00 & 80 & 8 & 12 & 0.02 \\
\hline & 3 & 6.80 & 5.64 & 3.50 & 10 & 1.37 & 2.30 & 2.60 & 12.30 & 26.20 & 82 & 7 & 11 & 0.04 \\
\hline & Ct. & 7.24 & 5.87 & 3.11 & 8 & 1.00 & 2.00 & 1.80 & 8.90 & 20.00 & 83 & 6 & 11 & 0.02 \\
\hline
\end{tabular}

$\mathrm{O} / \mathrm{C}=$ Organic Carbon, AP = Available Phosphorus, $\mathrm{TN}=$ Total Nitrogen, $\mathrm{Ct}$. = Control, $\mathrm{N}=\mathrm{Nitrogen}, \mathrm{P}=\mathrm{Phosphorus}$, and $\mathrm{K}=\mathrm{Potassium}, \mathrm{N}-\mathrm{F}, \mathrm{N}-\mathrm{W}$ and N-S = Nitrogen; for fish feed, Wastewater and Soil samples respectively, P-F, P-W and P-S = Phosphorus; for fish feed, Wastewater and Soil samples respectively, K-F, K-W and K-S = Potassium; for fish feed, Wastewater and Soil samples respectively.

Table 4. Proximate Composition of the fish feeds.

\begin{tabular}{ccccc}
\hline \multirow{2}{*}{$\boldsymbol{S} \boldsymbol{N}$} & Analysis & \multicolumn{3}{c}{ Compounded feed (\%) } \\
\cline { 3 - 4 } & & Foreign Feed & National produced feed Locally produced feed \\
\hline 1 & Crude Protein & 44.3 & 42.9 & 48.3 \\
2 & Crude Lipid & 11.5 & 11.8 & 13.0 \\
3 & Moisture & 8.1 & 8.5 & 9.3 \\
4 & Ash & 6.8 & 9.3 & 14.8 \\
5 & Crude Fibre & 2.6 & 1.8 & 4.7 \\
\hline
\end{tabular}

Table 5. Mineral Composition of the fish feeds.

\begin{tabular}{ccccc}
\hline \multirow{2}{*}{$S / N$} & Analysis & Foreign Feed & National produced feed Locally produced feed \\
\cline { 3 - 5 } & & 7.09 & 6.86 & 7.73 \\
\hline 1 & Nitrogen (\%) & 0.33 & 0.29 & 0.53 \\
2 & Phosphorus (\%) & 0.70 & 0.58 & 0.26 \\
3 & Potassium (\%) & & \\
\hline
\end{tabular}

Table 6. Correlation coefficients ( $\mathrm{r}$ ) between N, P and K for the study area.

\begin{tabular}{cccccccccc}
\hline & $N-F$ & $P-F$ & $K-F$ & $N-W$ & $P-W$ & $K-W$ & $N-S$ & $P-S$ & $K-S$ \\
\hline N-F & 1.000 & & & & & & & & \\
P-F & 0.930 & 1.000 & & & & & & & \\
K-F & -0.876 & 0.517 & 1.000 & & & & & & \\
N-W & 0.853 & -0.787 & -0.821 & 1.000 & & & & & \\
P-W & -0.487 & -0.468 & -0.697 & 0.704 & 1.000 & & & & \\
K-W & -0.373 & -0.328 & 0.711 & 0.311 & -0.586 & 1.000 & & & \\
N-S & 0.594 & 0.589 & 0.341 & -0.291 & 0.255 & -0.825 & 1.000 & & \\
P-S & 0.495 & 0.612 & 0.260 & -0.387 & 0.155 & -0.764 & 0.994 & 1.000 & \\
K-S & -0.808 & -0.421 & -0.618 & 0.731 & 0.263 & 0.432 & -0.865 & -0.911 & 1.000 \\
\hline
\end{tabular}




\section{1. $\mathrm{pH}$}

The $\mathrm{pH}$ value indicates the degree of acidity or alkalinity in water [22]. The $\mathrm{pH}$ value obtained from this study indicated that the wastewater from the various fish pond sites ranges between 6.79 and 6.87 while the value of $\mathrm{pH}$ for fresh water used to feed the ponds ranges between 6.95 and 7.10 while the soil samples ranged from 6.20 - 7.24. This result shows that the water samples (both wastewater and freshwater) were fragile in acid and alkaline content. The $\mathrm{pH}$ values obtained for the control soil sample were observed to be quite higher than those soil samples which come in contact with wastewater from the fish pond (FP). The $\mathrm{pH}$ values of the fish wastewater were lower than that of the source water used for the FP. These values were compared with international standards of WHO and FAO [26] [27], and they were found to be within their acceptable limits.

\subsection{Electrical Conductivity $\left(\mathrm{E}_{\mathrm{c}}\right)$}

The $\mathrm{E}_{\mathrm{c}}$ is used to measure the salt concentration in any water, it measures the strength of any water body to conduct electricity, and this is expressed in $\mu \mathrm{S} / \mathrm{cm}$ [22]. Over the years, it was reported that high values of conductivity were an indication of pollution when the $\mathrm{E}_{\mathrm{c}}$ values were compared with standards obtained from the World Health Organization [26]. It was discovered from this study that the $\mathrm{E}_{\mathrm{c}}$ of the wastewater from the FP ranged between $121-142 \mu \mathrm{s} / \mathrm{cm}$ while that of the source water ranged between $205-230 \mu \mathrm{s} / \mathrm{cm}$ for the borehole water and $118 \mu \mathrm{s} / \mathrm{cm}$ for the river water. These values were found to be within the recommended range when compared with the works of Muamar et al. [7]. This clearly shows that the wastewater water does not contain enough salt that will be of concern to the growth of fish. This further implies that it can be used for irrigation purposes. The results also show that the source water used for feeding the ponds was relatively high which may be due to the accumulation of dissolved salt. The results were similar to the works of Colt et al. [28].

\subsection{Turbidity}

Turbidity is a measure of the cloudiness of water. The higher the turbidity, the harder it is to see through the water and is usually affected by factors such as clay particles and particulate organic matters [22]. The Turbidity value for the Fish wastewater ranged between 130 - 159 NTU while the borehole water source ranged from 5 - 10 NTU and the river water source was found to be the highest at $620 \mathrm{NTU}$. The value obtained for the river source water was found to be very high which might be as a result of significant deposition of clay particles into the water body. The values obtained from this study when compared with the work of Torimiro et al. [29] showed a high level of similarity.

\subsection{Total Dissolved Solid (TDS)}

TDS is an indication of the number of dissolved substances inside the water [30]. 
The TDS values obtained for the Fish wastewater ranged between $330-407$ $\mathrm{mg} / \mathrm{L}$; the borehole water source ranged from 118 to $120 \mathrm{mg} / \mathrm{L}$ while the river source water had the highest value of $620 \mathrm{mg} / \mathrm{L}$. The high value obtained from the river water source might have to be due to significant deposition of solid sediments into the water. These results were also similar to the values obtained from the works of Ehiagbonare and Ogunrinde [31]. The osmotic pressure of the soil increases when the TDS is present in large quantities thereby causing high soil moisture stress in the root zone which in turn hinder plant growth and subsequently affect crops yield [22].

\subsection{Alkalinity}

Water alkalinity is due to the presence of dissolved salts from weak acids, bicarbonates and organic sulphates [20]. The alkalinity values obtained for the Fish wastewater ranged between $128-140 \mathrm{mg} / \mathrm{L}$; for the borehole source water used for the FP ranges between $80-148 \mathrm{mg} / \mathrm{L}$ while the river water source had a tremendously high value of $190 \mathrm{mg} / \mathrm{L}$. These values are found to be within the accepted range of WHO [26] and were similar to the values obtained in the works of Temilola et al. [21].

\subsection{Total Hardness (TH)}

According to WHO [26], the permissible level of total hardness in any water is $600 \mathrm{mg} / \mathrm{L}$, which in most cases comprises of Calcium carbonate $\left(\mathrm{CaCo}_{3}\right)$ or Magnesium carbonate $\left(\mathrm{MgCo}_{3}\right)$. The $\mathrm{TH}$ of the Fish wastewater for the various study locations ranged between 255 - $322 \mathrm{mg} / \mathrm{L}$; while the borehole water source ranged between 110 and $330 \mathrm{mg} / \mathrm{L}$ while that of the river source water was 400 $\mathrm{mg} / \mathrm{L}$. This indicates that the source of water from the river is harder than the wastewater. These results obtained were found to be similar to a study carried out by Simerjit [20].

\subsection{Temperature}

The temperature of a system is the degree of hotness or coldness in the body of the Organism. The result obtained from this study shows that the temperature value for the fish wastewater ranged between $26.9-29^{\circ} \mathrm{C}$ while the temperature result for the source water ranged from $26.9-29.0^{\circ} \mathrm{C}$. The result shows that the temperature values are within recommended standards for the survival of the fishes in water [26] [32] [33].

\subsection{Biological Oxygen Demand (BOD)}

BOD is a measure of the quantity of oxygen used by microorganisms (aerobic bacteria) in the oxidation of organic matter. A sample with BOD between 1.0 and $2.0 \mathrm{mg} / \mathrm{L}$ indicates clean water, BOD of 3.0 to $5.0 \mathrm{mg} / \mathrm{L}$ indicates a moderately clean water and if the value is more significant than $5 \mathrm{mg} / \mathrm{L}$, indicates a polluted water source, which means the water should be treated before been put 
to used [34]. The result obtained showed that the BOD values ranged between 4.0 to $6.0 \mathrm{mg} / \mathrm{L}$ for fish wastewater while those of the borehole and river water sources $3.0-3.7 \mathrm{mg} / \mathrm{L}$ respectively. These values obtained were found to be within the range for optimum fish activities and so within the recommended standard [26] [27].

\subsection{Dissolved Oxygen (D0)}

This is defined as the measure of the amount of gaseous oxygen dissolved in any water body [30]. Eze and Ogbaran [33] reported that natural water bodies are filled with dissolved oxygen. The DO for the fish wastewater ranged between 5.8 - $7.0 \mathrm{mg} / \mathrm{L}$ while the source water from the borehole and river had values ranging between 4.0 and $5.0 \mathrm{mg} / \mathrm{L}$ and $8.0 \mathrm{mg} / \mathrm{L}$ respectively. This makes the available maximum amount of oxygen for the survival of the fishes. The values obtained when compared with other literature were within the acceptable range [35].

\subsection{Nitrogen (N)}

The presence of moderate Nitrogen in soils is an essential element for plant growth, but its excess affects their growth and productivity [36]. The result obtained from this study showed that the Total nitrogen present in the soil after the wastewater deposit from the fish ponds ranged between 1.26 and $2.10 \mathrm{~g} / \mathrm{Kg}$ while the control soil samples ranged between 0.95 and $1.11 \mathrm{~g} / \mathrm{Kg}$. The nitrogen values obtained from the various feed samples used by the farmers showed that the values ranged between $6.86 \%$ and $7.73 \%$. This indicates that the quantity of nitrogen observed in the soil might have originated from the fish feeds and other sources such as; microorganisms and faeces present inside the ponds, thereby directly influencing the soil fertility when deposited on the soil. These results obtained showed that the Nitrogen level of the soil in contact with the fish wastewater is moderate when compared with the works of Nduka et al., [30] and is suitable for agricultural purposes. This may account for the quality and quantity of crops produced in the study area.

\subsection{Phosphorus (P)}

Phosphorus is anothervital macronutrient which has a direct effect on crop productivity in terms of quality and growth. It plays an essential role in bone development in animals [37]. The result obtained from this study showed that phosphorus values of the soils in contact with fish wastewater and that of the control soil samples ranged between $7-10 \mathrm{mg} / \mathrm{kg}$. The feeds analysed, suggest a rapid deposition of Phosphorus (Phosphate) into the fish wastewater due to the moderately high values of $0.29-0.53 \%$ obtained from the various feeds analysed. However, these values obtained were found to be within accepted range when compared with the works of Subramani et al., [37], which indicates that the application of the fish wastewater on the soil has minimal adverse effects 
on the soil.

\subsection{Potassium (K)}

Another essential macronutrient used up by plants is Potassium (K). This, according to Temilola et al. [21] activates enzymes which aid the formation of protein. It was observed from the results obtained for this study that there was an increase in the value of $\mathrm{K}$ in the soils in contact with fish wastewater than the control soils where wastewater from the fish ponds was deposited and compared to the control points of the soil samples. The $\mathrm{K}$ values obtained from the wastewater samples ranges between 1.5 and $4.5 \mathrm{mg} / \mathrm{kg}$ while the control soil sample values ranged between $0.9-1.8 \mathrm{mg} / \mathrm{kg}$. However, the fish feeds analysis gave high $\mathrm{K}$ values ranging between $0.26-0.70 \%$ when compared with the values obtained for the soil samples. The increase in the $\mathrm{K}$ values for the various wastewater is linked to the feeds used on the various farms which in-turn accounts for its high content in the soils where such are deposited. These values when compared to the works of Hassan et al., [38]; Desai et al., [39] and Temilola et al. [21] were found to be similar which suggests the deposition of $\mathrm{K}$ from the fish feeds into pond water and in turn to the soils.

\subsection{Magnesium (Mg)}

Magnesium is an essential component of chlorophyll, and it is required for the transport of phosphorus around the plant [38]. The magnesium content of the various soil samples where fish pond wastewater is deposited ranged between $10.4-17.9 \mathrm{mg} / \mathrm{kg}$ and the control ranged between 6.0 to $10.4 \mathrm{mg} / \mathrm{kg}$ for the river water source. While the Magnesium content of the soil samples in contact with the fish wastewater ranged between $12.3-18.5 \mathrm{mg} / \mathrm{kg}$ while that of the control soilsamples ranged between 6.0 to $10.4 \mathrm{mg} / \mathrm{kg}$ in the various areas where the fish pond wastewaters are deposited shows the effect of leaching and distance from the ponds. However, the Mg content of the source waters used for the various fish ponds ranges between 20.61 and $38.23 \mathrm{mg} / \mathrm{L}$ for the borehole and river source waters were between 20.52 and 28.19 and $30.23 \mathrm{mg} / \mathrm{L}$ respectively. These values were found to be within an acceptable range when compared with the works of Jaji et al. [40]; FAO [27] and Ahaneku [41].

\subsection{Calcium (Ca)}

Calcium in the soil, according to Liu et al., [42] and Liu et al., [43]; helps in the proper functioning of the root tips of growing plants and maintaining the strength of the various plant cell walls. Calcium present in fish pond wastewater ranged between 19.34 and $24.20 \mathrm{mg} / \mathrm{L}$ while that of the boreholes used to provide water to the various ponds ranges between 26.26 and $32.30 \mathrm{mg} / \mathrm{L}$ and that of the river water was $31.03 \mathrm{mg} / \mathrm{L}$. It is observed from these results that some quantity of the $\mathrm{Ca}$ is used by the fishes and other organisms in the ponds to enhance their growth which caused the reduction of the values of the calcium in the 
wastewater from FPs. The values of the Ca content where wastewater from FPs was deposited showed a staggering value of between 24.4 and $41.2 \mathrm{mg} / \mathrm{L}$ while soil samples from control points ranged between 8.9 and $20.0 \mathrm{mg} / \mathrm{L}$. These values when compared with the WHO [26] values of $200 \mathrm{mg} / \mathrm{L}$ were found to be within limits for optimum productivity of fish. It would, therefore, be necessary to have some forms of calcium supplement since calcium is necessary for bone and scale formation.

\subsection{Sodium (Na)}

Sodium in the soil is not a plant nutrient; hence it is not necessary for the growth and development of plants. When present in high levels, it is harmful to soil structure and also plants growth [42]. He also stated that high sodium could also displace other cations such as $\mathrm{Ca}$ and $\mathrm{Mg}$ into soil solution and they can subsequently be leached down the soil profile. The values obtained for the soil samples in contact with the fish wastewater ranged between $1.5-3.2 \mathrm{mg} / \mathrm{kg}$ while that of the control soil samples ranged between $1.3-2.0 \mathrm{mg} / \mathrm{kg}$. The $\mathrm{Na}$ content for the boreholes and river water sources ranged between 3.00 and $3.20 \mathrm{mg} / \mathrm{L}$ and 8.8 $\mathrm{mg} / \mathrm{L}$ respectively. The $\mathrm{Na}$ content of the wastewater from the various FPs ranged between 132 and $160 \mathrm{mg} / \mathrm{L}$. This shows that a high amount of $\mathrm{Na}$ is generated as waste by the fishes. This is connected to the feed component which in most cases is negligible. The values obtained were found to be lower when compared with the work of Devi et al. [36].

\subsection{Phosphate}

Phosphorous plays a vital role in the growth of plants and animals as they are known to serve as sources of phosphates fertilisers. Phosphorous helps to stimulate the growth of water plants and several microorganisms that provide food for fishes [36]. The values of Phosphate for the fish wastewater obtained from this study ranged between $0.51-1.30 \mathrm{mg} / \mathrm{L}$ while the borehole and river water sources ranged between $0.11-0.32 \mathrm{mg} / \mathrm{L}$ and $0.65 \mathrm{mg} / \mathrm{L}$ respectively. These values were found to be within the recommended range for optimum fish productivity and also similar to the values obtained by Torimiro et al. [29].

\subsection{Nitrate}

Nitrate is formed through a nitrification process by the action of aerobic bacteria, and it is highly stable in water [36]. The values of Nitrate for the fish wastewater obtained from this study ranged $2.53-3.45 \mathrm{mg} / \mathrm{L}$ while those of the borehole and river water sources ranged between 4.02 and $4.13 \mathrm{mg} / \mathrm{L}$ and $6.05 \mathrm{mg} / \mathrm{L}$ respectively. These values obtained were found to be within the recommended range when compared with the works of Carmago et al., [44] and Torimiro et al. [29]. The Nitrate value for the river water source was found to be quite high which indicated the level of pollution in the source of water used. The level of pollution is not distant from the leaching processes that occur from the surrounding soil environment. 


\subsection{Particle Size Analysis}

The measured values of particle size of sand, silt and clay ranged between $72 \%$ to $83 \%$; $6 \%$ to $9 \%$ and $10 \%$ to $19 \%$ respectively. From these results, the proportion of sand was found to be highest followed by that of clay and silt respectively. Thus, non-water loving crops do well in this area. This values obtained showed that a large portion of the soils are sandy and falls into the loamy sand textual class, and this soil texture can easily be felt by just simply touching the soil sample. The loamy soils found within the study area are the typical type of soils found in Minna the southern guinea ecological zone of Nigeria, thus indicating that the soils are moderately porous which means that not much is lost or retained. This textural soil class tends to favour the growth and productivity of crops such as Maize, Groundnut, Sorghum [37]. This statement was confirmed to be accurate as evidence of cereal crops were seen growing around the vicinity of where the fish pond wastewater was deposited.

\subsection{Correlation Analysis}

Pearson's correlation analysis was done to determine the degree of relationship between the wastewater, soils and the fish feed samples. The result of the analysis showed that there was a relationship between the Nitrogen $(\mathrm{N})$, Phosphorus $(\mathrm{P})$ and Potassium $(\mathrm{K})$ contents of the samples analysed. The correlation coefficient (r) of Nitrogen in wastewater and soil were 0.853 and 0.594 respectively. This was found to be positively correlated with the Nitrogen content in the various fish feed samples with the $\mathrm{p}<0.05$. This indicates that the increase in Nitrogen in the feeds increases the Nitrogen content in wastewater and the surrounding soil environment. The results also indicated that Nitrogen, Phosphorus and Potassium were significantly correlated with each another and was observed to be in line with the findings of Devi et al., [36], Ehigbonare and Ogunrinde [31] and Torimiro et al., [29]. Nitrogen in the Feeds was positively correlated with Phosphorus in the Feeds and Soil samples with a correlation coefficient of 0.930 and 0.495 respectively, while it was negatively correlated with Potassium in the Feeds, Wastewater, Soil samples and Phosphorus in the Wastewater with a correlation coefficient of $0.876,0.373,0.808$ and 0.487 respectively. This was also observed to be in line with the findings of Hussain et al. [45].

\section{Conclusions}

The effect of fish wastewater was analysed on the bases of the chemical and physical properties of the soil. From the results obtained it can be concluded that most of the parameters considered for the fish wastewater were also present in the soil samples in varying proportions and the application of fish wastewater on the soil improve the nutrients requirements of the soil.

The wastewater, therefore, has minimal adverse effects on the soil when deposited due to its mineral concentrations in the soil when the results were compared with the FAO standards of 2008. However, the concentration of miner- 
als/nutrient can exceed required limits when the fish wastewater is discharged on soils that had already been fertilised by artificial means. The fish wastewater can also be treated to further meet with various recommended standards for irrigation. The adverse effects of Fish wastewater on the soil physicochemical property are negligible, but these effects on tender crops such as spinach should be studied so as not to create health problems to the consumers of such farm produce.

\section{Conflicts of Interest}

The authors declare no conflicts of interest regarding the publication of this paper.

\section{References}

[1] Al-Absi, M. and Khalid, A. (2008) Characteristics of Purna River Water of Navsari and Removal of Trace Toxic Metals by Ion-Exchange Process Using Pre-Concentration Techniques. Journal of Pollution Research, 24, 415-422.

[2] Hussain, K.A. (2007) Effects of Sewage Wastewater Irrigation on Soil Properties, Crop Yield and Environment. Agricultural Journal of Water Management, 103, 100-104. https://doi.org/10.1016/j.agwat.2011.10.022

[3] Mike, K.A. (2008) Evaluation of Ground Water Quality in Lagos City. Journal of Applied Science, 13, 780-1784.

[4] Goyal, P. and Shukle, R. (2015) Physiochemical and Bacteriological Quality in Various Sources of Drinking Water from Auriya District (UP) Industrial Area. Journal of Pollution Research, 23, 205-207.

[5] Rattan, R.K., Datta, S.P., Chhonkar, P.K., Suribabu, K. and Singh, A.K. (2005) Long-Term Impact of Irrigation with Sewage Effluents on Heavy Metal Content in Soils, Crops and Groundwater. Journal of Agricultural Ecosystem and Environment, 109, 310-322. https://doi.org/10.1016/j.agee.2005.02.025

[6] Kiziloglu, F.M., Turan, M., Sahin, U., Kuslu, Y. and Dursun, A. (2009) Effects of Untreated and Treated Wastewater Irrigation on Some Chemical Properties of Cauliflower and Red Cabbage Grown on Calcareous Soil in Turkey. Journal of Agricultural Water Management, 95, 716-724. https://doi.org/10.1016/j.agwat.2008.01.008

[7] Muamar, A., Tijane, M., EL-Ariqi, S., El-Housni, A., Zouahri, A. and Bouksaim, M. (2014) Assessment of the Impact of Wastewater Use on Soil Properties. Journal of Material and Environmental Science, 5, 747-752.

[8] Namara, R.E., Hanira, M.A., Castillo, G.E., Raynborg, H.M., Smith, L. and Van Koppen, B. (2010) Agricultural Water Management and Poverty Linkages. Agricultural Water Management, 97, 520-527. https://doi.org/10.1016/j.agwat.2009.05.007

[9] Forenshell, G. (2006) A Preliminary Study of Medical Waste Management in Lagos Metropolis, Nigeria. Iranian Journal of Environmental Health, Science and Engineering, 9, 205-209.

[10] Roy, K., Chari, M.S., Gaur, S.R. and Thakur, A. (2014) Ecological Dynamics and Hydrobiological Correlations in Freshwater Ponds-Recent Researches and Application. International Journal of Environmental Biology, 4, 112-118.

[11] Capkin, E., Altinoc, I. and Karahan, S. (2006) Water Quality and Fish Size Affect Toxicity and Endosulfan, an Organochlorine Pesticide to Rainbow Trout. Chemosphere, 64, 1793-1800. https://doi.org/10.1016/j.chemosphere.2005.12.050 
[12] Tripathi, D.M., Tripathi, S. and Tripathi, B.D. (2011) Implications of Secondary Treated Distillery Effluent Irrigation on Soil Cellulase and Urease Activities. Journal of Environmental Protection, 3, 655-661. https://doi.org/10.4236/jep.2011.25075

[13] Raschid, L. (2007) Effect of Treated Wastewater on Soil Chemical and Physical Properties in Arid Regions. Journal of Plant and Soil Environment, 52, 335-344. https://doi.org/10.17221/3450-PSE

[14] Hanjra, M.A. (2009) Footprints of Water and Energy Inputs in Food Production Global Perspectives. Food Policy, 34, 130-140. https://doi.org/10.1016/j.foodpol.2008.09.001

[15] Narwal, R.P. (2008) Effect of Paper Mill Effluent's Irrigation on Soil and Plants. Journal of Biological and Environmental Science, 5, 71-76.

[16] Antil, R.S. and Dinesh, D.S.S. (2007) Utilization of Sewer Water and Its Significance in INM. Proceedings of ICAR Sponsored Winter School on Integrated Nutrient Management, Department of Soil Science and Directorate of Human Resource Management, CCS Haryana Agricultural University, Hisar, India, 9-83.

[17] Bajwa, H. (2008) Water Contamination Causing DNA Mutation. Chandigarh Edition, The Indian Express, India, 5.

[18] Musa, J.J. and Egharevba, N.A. (2009) Soil Grouping of the Federal University of Technology, Minna, Main Campus Farm Using Infiltration Rate. AU Journal of Technology, 13, 19-28.

[19] Nauman, M. and Khalid, S.K. (2010) Heavy Metals Contamination of Soils in Response to Wastewater Irrigation in Rawalpindi Region, Pakistan. Journal of Agricultural Science, 47, 215-224.

[20] Simerjit, K. (2012) Impact of Industrial Development on Groundwater \& Surface Water Quality in Industry Dominating Sectors of Chandigarh, India. Journal of Environment and Ecology, 3, 21-60. https://doi.org/10.5296/jee.v3i1.2182

[21] Temilola, O., Oluwatoyin, A. and Emmanuel, A. (2014) Impact Assessment of Dumpsites on Quality of Near-by Soil and Underground Water: A Case Study of an Abandoned and a Functional Dumpsite in Lagos, Nigeria. International Journal of Science, Environment and Technology, 3, 1004-1015.

[22] Agbaire, P.O., Akporido, S.O. and Emoyan, O.O. (2015) Determination of some Physicochemical Parameters of Water from Artificial Concrete Fish Ponds in Abraka and Its Environs, Delta State, Nigeria. International Journal of Plant, Animal and Environmental Sciences, 5, 2231-4490.

[23] Ayuba, V.O. and Iorkohol, E.K. (2013) Proximate Composition of Some Commercial Fish Feeds sold in Nigeria. Journal of Fisheries and Aquatic Science, 8, 248-252. https://doi.org/10.3923/jfas.2013.248.252

[24] Amin, M. (2011) Effects of Municipal Wastewater on Physical and Chemical Properties of Saline Soil. Journal of Biological and Environmental Science, 5, 71-76.

[25] Ojobor, S.A. and Tobih, F.O. (2015) Effects of Fish Pond Effluent and Inorganic Fertilizer on Amaranthus Yield and Soil Chemical Properties in Asaba, Delta State, Nigeria. Journal of Agriculture and Environmental Sciences, 4, 237-244. https://doi.org/10.15640/jaes.v4n1a29

[26] WHO (2009) Guideline for Drinking Water Quality. World Health Organization (WHO), Geneva, Switzerland.

[27] FAO (2008) Fish Pond Construction and Management. Field Guide and Extension Manual. Food and Agricultural Organization (FAO) with the National Special Programme for Food Security (NSPFS), Rome, Italy, 8-23. 
[28] Colt, J., Ludwig, R., Tchobanoglous, G. and Cech Jr., J.J. (1981) The Effects of Nitrite on the Short-Term Growth and Survival of Channel Catfish, Ictalurus Punctatus. Aquaculture, 24, 111-122. https://doi.org/10.1016/0044-8486(81)90048-X

[29] Torimiro N., Bebe, P.T., Ogundipe, F.E., Esan, D.M. and Aduwo, A.I. (2014) The Bacteriology and Physico-Chemical Analysis of Freshwater Fish Ponds. International Research Journal of Microbiology, 5, 28-32.

[30] Nduka, J.K., Orisakwe, O.E. and Ezenweke, L.O. (2008) Some Physicochemical Parameter of Potable Water Supply in Warri, Niger Delta Area of Nigeria. Scientific Research and Essay, 3, 547-551.

[31] Ehigbonare, J.E. and Ogunrinde, Y.O. (2010) Physicochemical Analysis of Fish Pond Water in Okada and Its Environs, Nigeria. Africa Journal of Biotechnology, 9, 5922-5928.

[32] Samara, F., Elsayed, Y., Soghomonian, B. and Knuteson, S.L. (2016) Chemical and Biological Assessment of Sediments and Water of Khalid Khor, Sharjah, United Arab Emirates. Marine Pollution Bulletin, 111, 268-276. https://doi.org/10.1016/j.marpolbul.2016.06.107

[33] Eze, V.C. and Ogbaran, I.O. (2010) Microbiological and Physicochemical Characteristics of Fish Pond Water in Ughelli Delta State, Nigeria. International Journal of Current Resources, 3, 82-87.

[34] Ezeanya, N.C., Chukwuma, G.O., Nwaigwe, K.N. and Egwuonwu, C.C. (2015) Standard Water Quality Requirements and Management Strategies for Fish Farming (A Case Study of Otamiri River). International Journal of Research in Engineering and Technology, 4, 1-5. https://doi.org/10.15623/ijret.2015.0403001

[35] Devi, P., Sirisha, D. and Gandhi, N. (2013) Study on the Quality of Water and Soil from Fish Pond in Around Bhimavaram West Godavari District, A.P., INDIA. International Research Journal of Environment Sciences, 2, 58-62.

[36] Nájera, F., Tapia1, Y., Baginsky, C., Figueroa, V., Cabeza1, R. and Salazar, O. (2015) Evaluation of Soil Fertility and Fertilisation Practices for Irrigated Maize (Zea mays L.) under Mediterranean Conditions in Central Chile. Journal of Soil Science and Plant Nutrition, 15, 84-97.

[37] Subramani, T., Mangaiyarkarasi, M. and Kathirvel, C. (2014) Impact of Sewage and Industrial Effluent on Soil Plant Health Act on Environment. International Journal of Engineering Research and Applications, 4, 270-273.

[38] Hassan, F.M., Kathim, N.F. and Hussain, F.H. (2008) Effect of Chemical and Physical Properties of River Water in Shatt Al-Hilla on Phytoplankton Communities. Journal of Chemistry, 5, 323-330. https://doi.org/10.1155/2008/940542

[39] Desai, S.R., Subash, C.M.D. and Ramachandra, T.V. (2008) Phytoplankton Diversity in Sharavati River Basin, Central Western Ghats. The ICFAI University Journal of Soil and Water Sciences, 1, 7-66.

[40] Jaji, M.O., Bamgbose, O., Odukoya, O.O. and Arowolo, T.A. (2007) Water-Quality Assessment of Ogun River, South West Nigeria. Environmental Monitoring and Assessment, 133, 473-482. https://doi.org/10.1007/s10661-006-9602-1

[41] Ahaneku, I.E. (2014) Effect of Land Application of Dairy Effluent on Soil Physical and Chemical Properties. Research Journal of Pharmaceutical, Biological and Chemical Sciences, 5, 16-69.

[42] Liu, G., Wang, R., Wu, L., Peng, S., Wang, Y. and Jiang, C. (2015) Differential Changes in Cell-Wall Content and Boron and Calcium Concentration in Newhall Navel Orange Grafted on Two Rootstocks Differing in Boron-Deficiency Responses. Communications in Soil Science and Plant Analysis, 46, 439-453. 
https://doi.org/10.1080/00103624.2014.997384

[43] Liu, Y., Song, H., Zhang, J. and Richardson, M.D. (2016) Growth Characteristics of Bahiagrass Roots Treated with Micronutrients, Rare Earth Elements, and Plant Hormones. HortTechnology, 26, 176-184.

https://doi.org/10.21273/HORTTECH.26.2.176

[44] Carmago, J.A., Alonso, A. and Salamanca, A. (2005) Nitrate Toxicity to Aquatic Animals: A Review with New Data for Freshwater Invertebrates. Chemosphere, 58, 1255-1267. https://doi.org/10.1016/j.chemosphere.2004.10.044

[45] Hussain, M., Hussain, S.M., Afzal, M., Javid, A., Abdullah, S., Raza, S.A. and Iqbal, M. (2011) Effect of Low Level of Mineral Phosphorus and Medium Level of Nitrogen on Planktonic Productivity and Increase in Fish Production. The Journal of Animal \& Plant Sciences, 21, 642-645. 